\title{
Peran Employee Relationship Proneness Terhadap Sikap Dan Perilaku Loyalitas Karyawan Rumah Sakit Islam Ibnu Sina Pekanbaru
}

\author{
ZULIA KHAIRANI \\ Fakultas Ekonomi Universitas Lancang Kuning \\ Jl. Yos Sudarso KM 8 Rumbai \\ Telp. (0761) 52581 email ; khairani.zulia@gmail.com
}

\begin{abstract}
This study is aimed at understanding and discovering the influence of employee relations towards the loyalty attitude dimension. Furthermore, It also attempts to find out and comprehend the impact of loyalty attitude dimension of employee on each of the dimension. The data of this research was gathered by mean of questionnaires which were delivered to 130 respondent selected using purposive sampling. Structural Equation Modeling (SEM) had been used as the main analysis technique. The result of this study demonstrates that the tendency of employee relation has a significant positive role in building effective commitment. Conversely, it does not show any significant positive role on both calculative and normative commitment. In addition, It is also observed that affective commitment has only positive significant role in building intention to stay attitude. Meanwhile, calculative and normative commitment have resulted in insignificant positive role towards intention to stay. Each of the loyalty attitude dimensions; affective, calculative and normative commitments have no significant role towards positive variable dimensions (WOM), insensitivity towards benefit and complain.
\end{abstract}

Keywords: Employee Relationship Proneness, attitude, behavior, loyality.

Dalam pemasaran jasa, kualitas sangat berhubungan erat dengan performa karyawan. Oleh karena itu untuk membangun kompetensi yang paling penting adalah membentuk karyawan yang memiliki komitmen tinggi terhadap perusahaan (Andrian, 2010). Hal ini mendukung upaya perusahaan guna mencapai superioritas dan efisiensi dalam perusahaan karena pada dasarnya highly-committed employees akan berbuat yang terbaik bagi perusahaannya. Karyawan merupakan aset yang penting bagi perusahaan jasa oleh karena kemampuan elemen ini untuk menciptakan perbedaan yang dapat menciptakan kepuasan dan loyalitas pelanggan. Kehandalan karyawan selama proses transfer menjadi stimulus bagi pembentukan persepsi konsumen akan kinerja jasa. Emosi dan perasaan konsumen sangat dipengaruhi oleh pertemuan dengan karyawan.

Salah satu bentuk jasa kesehatan adalah rumah sakit dimana di Indonesia dewasa ini menunjukkan suatu kecenderungan peningkatan kompetisi yang kian besar (Primalita, 2008). Sekarang ini mayoritas rumah sakit yang ada di Indonesia sudah bergeser ke arah profit oriented, hal ini disebabkan karena masuknya Indonesia ke dalam persaingan pasar bebas yang mengharuskan kita untuk merubah cara pandang terhadap rumah sakit. Saat ini tidak memungkinkan lagi jika rumah sakit hanya dipandang sebagai institusi sosial. Dengan berjalannya waktu rumah sakit telah menjadi institusi yang bersifat sosio-ekonomis. Sehingga tidak heran sekarang ini banyak dibangun rumah sakit baru yang memiliki pelayanan seperti hotel berbintang, teknologi baru dan canggih, serta dikelola dengan manajemen profesional yang tentunya berorientasi profit.

Keluarnya Permenkes No. 80/Menkes/Per/II/90 yang menyatakan bahwa badan hukum termasuk perorangan diperkenankan memiliki dan mengelola rumah sakit dengan sifat profit oriented, membuat rumah sakit sadar untuk menerapkan manajemen pemasaran untuk bisa mempertahankan eksistensinya. Hal ini menimbulkan persaingan yang semakin ketat antar rumah sakit. Rumah sakit tidak hanya 
bersaing dengan rumah sakit lainnya tetapi juga harus bersaing dengan praktek bidan, praktek dokter dan pelayanan kesehatan lainnya. Hal ini menjadi sebuah tantangan tersendiri bagi rumah sakit untuk segera berbenah diri dalam meningkatkan kualitas pelayanan kesehatannya. Berkaitan dengan rumah sakit, pada tahun 2015 di kota Pekanbaru yang memiliki luas wilayah 632,26 km2 dan jumlah penduduk sekitar 754,000 jiwa terdapat 27 rumah sakit umum dan swasta (wikipedia.co.id).

Rumah Sakit Islam Ibnu Sina merupakan satu-satunya rumah sakit islam yang ada di kota Pekanbaru, berdiri pada tanggal 7 Januari 1980 berdasarkan pendirian Yayasan Rumah Sakit Islam (YARSI) Riau. Setelah 25 tahun berdiri, sesuai dengan perundang-undangan yang berlaku, tahun 2005 dilakukan perubahan kepengurusan rumah sakit dari yayasan kepada perseroan terbatas (PT) yang diberi nama PT Syifa Utama. Yayasan tidak lagi mengurusi Rumah sakit secara langsung, tetapi perseroan terbatas (PT) yang selanjutnya diberikan kewenangan untuk mengurus rumah sakit dengan mayoritas saham dimiliki oleh YARSI Riau.

Berdasarkan data dari HRD Rumah Sakit Islam Ibnu Sina, terlihat bahwa Rumah Sakit Islam Ibnu Sina banyak memiliki karyawan yang telah bekerja diatas 10 tahun dan kebanyakan berjenis kelamin perempuan. Hal ini menunjukkan bahwa perusahaan ini mampu mempertahankan karyawannya bekerja dalam jangka waktu lama. Berdasarkan hal tersebut sangat layak untuk diukur sikap dan perilaku loyalitas mereka terhadap perusahaan dan apa saja indikator yang mempengaruhi sikap dan perilaku loyalitas mereka terhadap Rumah Sakit Islam Ibnu Sina. Sehubungan dengan hal ini, maka peneliti tertarik melakukan penelitian tentang peran employee relationship proneness terhadap sikap dan perilaku loyalitas karyawan Rumah Sakit Islam Ibnu Sina Pekanbaru.

Untuk menjelaskan secara teoritis permasalahan tersebut digunakan beberapa teori sebagai berikut : Rumah sakit sebagai institusi jasa mempunyai ciri-ciri yaitu, tidak berwujud, merupakan aktivitas pelayanan antara tenaga medis dan non medis dengan pelanggan, tidak ada kepemilikan, konsumsi bersamaan dengan produksi dan proses produksi bisa berkaitan atau tidak dengan produk fisiknya (Prima Lita:2008). Hal ini sesuai dengan pendapat dari Zeithaml dan Bitner (2000:3) bahwa jasa memiliki ciri-ciri yaitu, (1) tidak berwujud, (2) merupakan suatu aktivitas, kegiatan atau kinerja, (3) tidak menyebabkan kepemilikan, (4) produksi dan konsumsi terjadi secara bersamaan, dan (5) proses produksinya berkaitan atau tidak berkaitan dengan produk fisik.

Menurut Kotler (2009:48), pemasaran internal merupakan hubungan timbal balik antara perusahaan dengan karyawannya. Tujuan yang hendak dicapai dari pemasaran internal ini adalah memberikan kepuasan dan motivasi kepada karyawan perusahaan untuk memberikan pelayanan yang terbaik bagi pelanggan. Pemasaran interaktif menggambarkan hubungan karyawan dengan pelanggan. Dalam hal ini karyawan sebagai bagian dari proses penyajian jasa berkewajiban untuk memenuhi janji yang telah ditetapkan oleh perusahaan kepada pelanggan.

Kotler (2009:49) menjelaskan Pemasaran internal merupakan hubungan timbal balik antara perusahaan dengan karyawannya. Menurut Supriyantono (2010;228), pemasaran internal merupakan suatu filosofi untuk mengelola sumber daya manusia organisasi berdasarkan perspektif pemasaran. Konsep pemasaran secara internal berawal dari bidang pemasaran jasa yang awalnya berkonsentrasi pada cara agar setiap orang yang terlibat dalam proses memberikan layanan dapat terus meningkatkan kualitas interaksi dan pelayanan yang diberikan kepada pelanggan (Gummesson, 2000 :27).

Menurut Supriyantono (2010:229), hasil langsung pemasaran internal adalah peningkatan komitmen dan loyalitas karyawan dan akhirnya peningkatan mutu layanan kepada pelanggan eksternal. 
Primalita (2008) menjelaskan bahwa kesadaran pentingnya untuk meretensi dan meningkatkan kompetensi karyawan dilandasi kenyataan bahwa biaya untuk merekrut karyawan yang berpotensi dan melatih sangat besar. Rumah sakit sebagai jasa kesehatan merupakan sistem pemasaran jasa dengan kontak yang tinggi (High-Contact Service) dan semua elemen pada sistem pemasaran jasa sagling terkait. Menurut Caruana et.al., (1998) bahwa keberhasilan penerapan internal marketing dapat dilihat dari sikap karyawan berdasarkan kerjanya termasuk komitmen organisasi, motivasi kerja, dan kepuasan kerja.

Kecendrungan hubungan pada karyawan (Employee Relationship Proneness) digambarkan sebagai suatu ciri kepribadian yang mencerminkan suatu kesadaran karyawan yang relatif stabil dan kecenderungan untuk terlibat dalam hubungan dengan perusahaan ( De Wulf et.al., 2001; Odekerken-Schröder et.al., 2001; Bloemer et.al., 2006). Hal ini sejalan dengan peran hubungan kerja pada karyawan sebagai variabel yang mengaktifkan proses psikologis dan yang mendasari komitmen karyawan tersebut pada perusahaan tempat mereka bekerja (Bloemer et.al., 2006). Menurut Chaplin (1995) kecenderungan merupakan satu set atau susunan sikap untuk bertingkah laku dengan cara tertentu. Kecenderungan suatu dorongan yang muncul dalam diri individu secara inheren menuju suatu arah tertentu, untuk menunjukkan suka atau tidak suka terhadap sesuatu objek.

Kecendrungan hubungan karyawan (Employee Relationship Proneness) berfokus pada motivasi positif karyawan untuk terlibat dalam suatu hubungan kerja dengan perusahaan mereka (Bendapudi dan Berry, 1997). Dalam konteks pelanggan,

Christy et.al., (1996) menggunakan istilah psikologis, cenderung untuk mengekspresikan gagasan bahwa beberapa individu secara intrinsik cenderung menjadi loyal. Dalam hal ini perusahaan yakin bahwa kecenderungan psikologis, yang berbeda antara karyawan, juga dapat diterapkan pada konteks penelitian saat ini.
Allen and Meyer (1990) dalam Bloemer et.al., (2006) menyatakan komitmen organisasional sebagai bagian sikap loyalitas ( Attitudinal Loyalty) dan membagi menjadi tiga tipe yaitu komitmen afektif (AC), komitmen kalkulatif (CC), dan komitmen normatif (NC). Perbedaan antara berbagai jenis sikap loyalitas mencerminkan keadaan psikologis yang mengikat karyawan untuk organisasi. Komitmen afektif (AC) mengacu pada pendekatan emosional karyawan pada organisasi, sedangkan komitmen kalkulatif (CC) mengacu pada biaya yang ditanggung karyawan jika meninggalkan organisasi dan komitmen normatif (NC) mengacu pada perasaan kewajiban yang dimiliki karyawan untuk tetap dengan organisasi. Mereka berpendapat, bahwa lebih komprehensif pemahaman tentang hubungan antara sikap loyalitas akan tercapai bila ketiga jenis komitmen betul-betul dipertimbangkan secara bersamaan.

Penelitian mengenai attitudinal commitment melibatkan pengukuran terhadap komitmen (sebagai sikap atau pola pikir), bersamaan dengan variable lain yang dianggap sebagai penyebab, atau konsekuensi dari komitmen (Buchanan \& Steers dalam Meyer \& Allen, 1997). Tujuan dari penelitian ini bertujuan untuk menunjukkan bahwa komitmen yang kuat menyebabkan terjadinya tingkah laku anggota organisasi sesuai dengan yang diharapkan (dari perspektif organisasi), seperti anggota organisasi jarang untuk tidak hadir dan perpindahan ke organisasi lain lebih rendah, dan produktivitas yang lebih tinggi. Tujuan yang kedua menunjukkan karakteristik individu dan situasi kondisi seperti apa yang mempengaruhi perkembangan komitmen berorganisasi yang tinggi.

Menurut Allen and Meyer dalam Bloemer et.al., (2006) menyatakan komitmen afektif (affective commitment) berkaitan dengan adanya keinginan untuk terikat pada organisasi atau keterikatan emosional karyawan, identifikasi, dan keterlibatan dalam organisasi terjadi apabila karyawan ingin menjadi bagian dari organisasi karena 
adanya ikatan emosional (emotional attachment) atau merasa mempunyai nilai sama dengan organisasi. Komitmen kalkulatif diartikan tetap bertahan dalam perusahaan, merupakan kebutuhan bagi individu, di landasi pertimbangan bahwa seseorang sudah terlalu besar menginvestasikan sumber daya, kapasitas pribadi (pengetahuan dan keterampilan) pada organisasi, sehingga sangat berisiko/mahal jika dia harus keluar dari perusahaan tempat bekerja (Allen dan Meyer, 1990).

Komitmen normatif adalah komitmen individu pada perusahaan karena adanya dorongan keyakinan seseorang untuk bertanggung jawab secara moral bahwa selayaknya harus loyal atau setia kepada organisasi (Allen dan Meyer, 1990, Brown dan Gaylor, 2002).

Perilaku loyalitas ( Behavioral Loyalty) yang dikembangkan oleh Bloemer et.al., (2006) melalui empat dimensi utama : Positif WOM (Positif Worth Of Mouth) adalah usaha pemasaran yang memicu konsumen untuk membicarakan, mempromosikan, merekomendasikan dan menjual produk atau merek kita kepada pelanggan lainnnya (Zeihaml et.al.,1996). Konsep pemasaran ini dikembangkan oleh Bloemer (2006) dalam bentuk Positif Word of Mouth pada karyawan, yang menggambarkan keinginan karyawan untuk mengatakan hal-hal yang positif tentang perusahaan terhadap pihak diluar perusahaan dan merekomendasikan perusahaan kepada orang lain; kedua, Keinginan menetap (Intention to Stay) adalah keinginan menetap digambarkan sebagai suatu niat pegawai untuk tetap meneruskan keanggotaannya pada suatu organisasi, dimungkinkan karena pertimbangan ekonomis, seperti biaya-biaya yang harus ditanggung jika pegawai memutuskan keluar atau menetap di suatu organisasi. Ketiga, Ketidakpekaan terhadap benefit (Benefit Insensitivity) berkaitan dengan kecenderungan karyawan untuk tidak peduli terhadap manfaat gaji atau balas jasa dan imbalan yang ditawarkan perusahaan lain. Keempat; komplain (Complaining) merupakan perilaku karyawan untuk memberikan kritik terhadap perusahaan, tidak melalui organisasi eksternal dan meninggalkan perusahaan tanpa pemberitahuan lebih lanjut.

Bloemer et.al., (2006) melakukan penelitian mengenai peran kecenderungan hubungan pada karyawan (Employee Relationship Proneness) dan pengaruhnya Terhadap Perilaku loyalitas (behavioral Loyalty) karyawan yang terdiri dari Positif Word Of Mouth, Intention to Stay, Benefit Insensitivity, dan Complaining melalui sikap loyalitas karyawan di beberapa bank di Belgia. Studi ini juga melihat bagaimana dampak dari peran hubungan kerja pada karyawan (Employee Relationship Proneness) pada tiga tipe sikap loyalitas yaitu komitmen afektif, komitmen kalkulatif, dan komitmen normatif. Hasil penelitian menemukan bahwa kecenderungan hubungan karyawan (Employee relationship Proneness) merupakan anteseden yang kuat dari komitmen afektif dan komitmen normatif. Komitmen afektif memiliki peranan penting dalam membentuk semua perilaku loyalitas yang terdiri dari positif WOM, keinginan menetap (Intention to stay), ketidakpekaan terhadap manfaat (benefit Insensitivity), dan complaining. Komitmen kalkulatif memiliki pengaruh negatif dan signifikan terhadap benefit insensitivity dan complaining. Sedangkan komitmen normatif hanya memiliki pengaruh yang signifikan terhadap keinginan menetap (Intention to stay) dan ketidakpekaan terhadap benefit (Benefit Insensitivity).

Primalallaz (2006) dalam penelitiaannya, Potential effects of psychological reactance and relationship proneness on relationships marketing programmes yang mengukur pengaruh dari reaksi psikologis dan relationship proness terhadap pengaruhnya pada program hubungan pemasaran. Dalam penelitian ini dikatakan ada pengaruh positif dari relationship proneness terhadap komitmen karyawan dan adanya hubungan antara kedua varibel ini. Allen dan Mayer (1990) dalam penelitiannya, The measurement and antecedents of affective, continuance and normative commitment to the organization, 
melakukan penelitian mengenai Komitmen organisasi yang telah dikonsep dan diukur dalam dua studi untuk menguji aspek-aspek dari model tiga-komponen komitmen.. Komponen afektif merujuk pada keterikatan emosional karyawan, identifikasi dan keterlibatan dalam komponen kalkulatif mengacu pada komitmen didasarkan pada biaya yang berhubungan dengan karyawan jika meninggalkan organisasi. terakhir, komponen normatif merujuk pada perasaan karyawan kewajiban untuk tetap dengan organisasi..

Pada dasarnya penelitian ini mengacu pada model penelitian yang telah dijalankan Bloemer (2006) dengan beberapa penyesuaian. Jika pada penelitian Bloemer, menggunakan peran kecendrungan hubungan kerja karyawan (Employee Relationship Proneness) terhadap sikap dan perilaku loyalitas karyawan pada beberapa Bank di Belgia, maka pada penelitian ini mengambil Rumah Sakit Ibnu Sina Pekanbaru, peneliti ingin melihat bagaimana efek dari employee relationship proneness pada tiga tipe sikap loyalitas yaitu komitmen afektif, komitmen kalkulatif, dan komitmen normatif pada Rumah Sakit yang juga termasuk dalam industri jasa. Dalam penelitian ini juga melihat bagaimana Pengaruh sikap loyalitas terhadap perilaku loyalitas yang terdiri dari positif WOM, Intention to stay, Benefit Insensitivity, dan Complain.

\section{METODE}

Penelitian ini menggunakan rancangan penelitian konklusif (conclusive research design) dalam bentuk penelitian kausal (causal research), karena perlu melihat beberapa variabel yang menjadi determinan terhadap variabel lain (Rangkuti, 2003). Sedangkan metode yang digunakan dalam penelitian ini yaitu metode survey berupa kuesioner sehingga didapatkan hubungan antar variabel dan wawancara sebagai teknik komunikasi langsung untuk memperoleh datadata yang diperlukan. Seperti yang dapat dilihat dalam kerangka penelitian, maka variabel dalam penelitian ini terdiri dari variabel bebas (independent variable) yang terdiri dari variabel kecendrungan hubungan pada karyawan (employee relationship Proneness), dan variabel terikat (dependent variabel) adalah perilaku loyalitas yang terdiri dari Positif WOM, Intention to stay, Benefit Insensitivity, Complaining.

Dalam penelitian ini ada variabel yang memiliki peran ganda yaitu variabel sikap loyalitas yang terdiri dari komitmen afektif, komitmen kalkulatif, dan komitmen normatif. Variabel ini berperan sebagai variabel terikat (dependent variabel) dari kecendrungan hubungan pada karyawan (Employee Relationship Proneness) dan sebagai variabel bebas (Independent Variabel) terhadap perilaku loyalitas.

Populasi dari penelitian ini adalah karyawan Rumah Sakit Islam Ibnu Sina dengan masa kerja diatas 1 tahun sebanyak 397 orang. Pada penelitian ini, jumlah indikator yang dipergunakan ada 20 indikator. Artinya diperlukan sampel antara 100-200 buah. Memperhatikan hal ini dan beberapa pertimbangan yaitu kemudahan dalam pengumpulan data, maka pada penelitian ini digunakan sampel sebanyak 130 responden. Metode pengambilan sampel yang digunakan adalah purposive sampling. Pengumpulan data dengan kuesioner. Kedelapan variabel menggunakan skala $1=$ sangat tidak setuju ... 5=sangat setuju.

$$
\text { Untuk analisa data dasar }
$$
menggunakan Partial Least Square (PLS) yang tidak mensyaratkan pemenuhan asumsi karena menggunakan component based analysis (Ghozali 2003). Namun tidak ada larangan pengujian, maka dilakukan pengujian normalitas, homogenitas, dan outliers data, agar hasil analisis semakin lengkap. Beberapa kelompok data berdistribusi tidak normal, tidak terjadi heteroskedastisitas, serta tidak terdapat data outliers.

\section{HASIL}

Dari model PLS awal terlihat ada 2 indikator yang bernilai tidak valid yaitu indikator $\mathrm{CC}_{2}$ pada dimensi variabel komitmen kalkulatif dan indikator $\mathrm{C}_{1}$ pada 
dimensi variabel komplain. Kedua indikator yang tidak valid tersebut selanjutnya di eliminasi, kemudian dilakukan evaluasi model menjadi model akhir seperti berikut ini:

\section{Gambar 1}

Hasil Pembentukan Model Akhir dengan menggunakan PLS

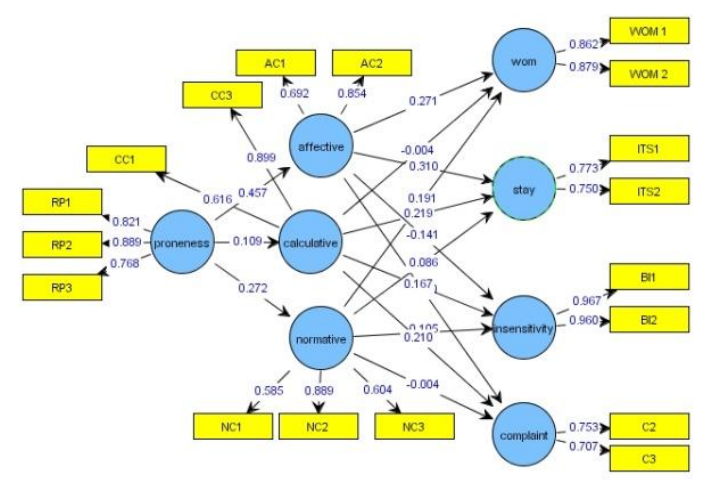

Sumber: Hasil pengolahan data sesuai lampiran

Nilai akar AVE pada Komitmen Afektif memperlihatkan nilai yang lebih tinggi dibanding nilai korelasinya dengan konstruk lainnya. Perhitungan Internal Consistency menghasilkan composite reliability sebesar 0,75 yang lebih besar dari 0,60. Artinya variabel komitmen afektif memiliki reliabilitas yang memadai untuk analisis selanjutnya. Pada variabel komitmen kalkulatif, memperlihatkan nilai akar AVE yang lebih besar dibanding nilai konstruknya dengan konstruk lainnya. Hal ini diperkuat pada hasil pengukuran Internal Consistency yang menghasilkan composite reliability sebesar 0,74 yang lebih besar dari 0,6. Dengan demikian dinyatakan komitmen kalkulatif adalah reliabel.

Hasil perhitungan internal consistency pada variabel komitmen normatif menghasilkan nilai composite reliability sebesar 0,74 yang lebih besar dari 0,60. Hal ini didukung oleh nilai akar AVE dari komitmen normatif yang lebih besar dibanding nilai korelasinya dengan 7 konstruk lainnya. Dengan demikian dinyatakan bahwa komitmen normatif adalah reliabel. Pada dimensi variabel positif word of mouth, intention to stay, benefit Insensitivity, dan Complain, memperlihatkan nilai akar AVE yang lebih besar dibanding nilai korelasinya dengan konstruk masing-masing. Hal ini diperkuat pada hasil pengukuran Internal Consistency yang menghasilkan composite reliability masing-masing sebesar 0,$86 ; 0,74$ ; 0,70 yang lebih besar dari 0,60. Dengan demikian dinyatakan masing-masing dimensi variabel positif word of mouth, intention to stay, benefit insensitivity dan komplain adalah reliabel.

\section{PEMBAHASAN}

Dalam penelitian ini menemukan bahwa Employee Relationship Proneness (Kecendrungan Hubungan Karyawan) merupakan variabel yang penting dalam membentuk komitmen afektif pada karyawan Rumah Sakit Islam Ibnu Sina di Pekanbaru. Pada dasarnya karyawan Rumah Sakit Islam Ibnu Sina memiliki kecendrungan hubungan yang positif terhadap perusahaan. Maksudnya disini, karyawan memiliki kecendrungan tingkat kesetiaan yang baik, ingin memiliki hubungan yang kuat, dan ingin berbuat lebih banyak terhadap Rumah Sakit Islam Ibnu Sina. Hal ini sesuai dengan pendapat Thoha (2008:34), karyawan sebagai individu yang memiliki kemampuan, kepercayaan pribadi, pengharapan-pengharapan, kebutuhan dan pengalaman masa lalunya sebagai karakter individu berinteraksi dengan tatanan dalam perusahaan : seperti peraturan dan wewenang, tugas-tugas dan tanggung jawab mereka dalam perusahaan. Mereka merasakan adanya kesesuaian dan perusahaan mampu memenuhi kemauan dan karakteristik individual mereka. Karyawan juga memiliki komitmen afektif yang kuat, yaitu memiliki keterikatan emosional yang kuat, identifikasi dan rasa memiliki terhadap perusahaan.

Hal ini juga sesuai dengan penelitian yang dilakukan Bloemer (2006) yang menemukan bahwa kecendrungan hubungan karyawan berpengaruh positif terhadap komitmen afektif pada karyawan bank di Belgia, dimana komitmen afektif berkaitan 
dengan keterikatan emosional karyawan, identifikasi karyawan, dan keterlibatan karyawan pada organisasi. Karyawan Rumah Sakit Islam Ibnu Sina ternyata memiliki hubungan keterikatan yang baik dengan perusahaan mereka dan kecenderungan hubungan yang baik itu mempengaruhi komitmen afektif mereka terhadap perusahaan.

Pada karyawan Rumah Sakit Islam Ibnu Sina, terdapat kecendrungan bahwa dalam organisasi mereka, nilai-nilai agama islam selalu dan terus menerus ditanamkan pada karyawan. Perusahaan selalu mengadakan ceramah dan siraman rohani di Masjid Asyifa (Masjid yang berada dalam lingkungan rumah sakit) minimal setiap dua kali seminggu. Para karyawan juga diberi pelatihan implementasi nilai-nilai islami yang diadakan di Rumah Sakit Islam Ibnu Sina. Pada karyawan juga sering diberikan penanaman nilai bahwa bekerja itu adalah ibadah, Hal ini dapat dilihat dari nilai-nilai yang ditanamkan dan disampaikan secara formal dan informal untuk karyawan, dimana dalam kegiatan keseharian pekerjaan karyawan-karyawan selalu dimotivasi untuk memiliki nilai-nilai: SYIFA UTAMA. Merupakan singkatan dari $S$ : Shiddiq (Rightness) Bertindak, bersikap dan berucap benar berdasarkan sifat-sifat jujur, terbuka, sabar, dan adil sehingga menjadi tauladan bagi orang lain $\mathrm{Y}$ : Yakin (Confidence) Memiliki rasa percaya diri yang tinggi yang didasarkan pada nilai-nilai Islam I : Ikhlas (Honesty) Bekerja, beribadah dan beramal semata-mata mencari keridhaan Allah F : Fathonah (Professional) Mengembangkan dan meningkatkan profesionalisme dalam bekerja A : Amanah (Trust) Memiliki integritas, komitmen dan bertanggung jawab $U$ : Ummah (Society) Melayani seluruh lapisan masyarakat tanpa membedakan ras, etnik, golongan dan agama T : Tawakkal (Faithful) Berikhtiar dengan upaya yang optimal dan berserah diri kepada Allah SWT A : Amar ma'ruf dan nahyi munkar (Goodness) Senantiasa mengajak kepada kebaikan dan mencegah gtkepada kemunkaran berdasarkan Alqur'an dan Alhadits $\mathrm{M}$ : Mustawa
(Excellent) Prima dalam pelayanan, menjadikan kepuasan pelanggan sebagai prioritas utama A : Aman (Safety) Mengutamakan keamanan dan kenyamanan dalam pelayanan yang berorientasi pada keselamatan pasien. Sesuai dengan hal ini lah nilai-nilai ibadah dalam sebuah pekerjaaan tertanam kuat pada diri karyawan. Sehingga karyawan yang memiliki kecenderungan hubungan yang baik dengan perusahaan melalui ikatan emosional yang kuat melalui nilai-nilai agama yang kuat ditanamkan perusahaan terhadap diri karyawan.

Selanjutnya Kecenderungan Hubungan pada Karyawan (Employee Relationship Proneness) mempengaruhi komitmen kalkulatif karyawan, tetapi pengaruhnya kecil dan tidak signifikan. Hal ini tidak sejalan dengan penelitian yang dilakukan Bloemer (2006) dimana menemukan Kecenderungan hubungan karyawan (Employee Relationship Proneness) memiliki pengaruh negatif terhadap komitmen kalkulatif. Perbedaan ini mungkin disebabkan karena karyawan mungkin merasakan bahwa jika mereka memiliki kecenderungan hubungan yang positif dengan perusahaan, mereka tentu saja berkomitmen bukan karena berdasarkan untung atau rugi saja. Mungkin hal ini karena perusahaan mampu memenuhi kebutuhan spritual mereka sehingga komitmen mereka berdasarkan untung rugi dalam bentuk materi pada perusahaan tidak terlalu diperhatikan. Sebagian karyawan juga merasa mampu untuk mendapatkan pekerjaan yang lebih baik dari pekerjaannya saat ini.

Pada komitmen normatif juga dipengaruhi employee relationship proneness (kecendrungan hubungan karyawan) dengan pengaruh yang positif tetapi tidak signifikan. Karyawan yang memiliki kecendrungan berkeinginan memiliki hubungan yang baik dengan perusahaan memiliki pengaruh yang tidak berarti terhadap komitmen normatif mereka dengan perusahaan secara signifikan. Hal ini disebabkan karyawan merasakan bahwa mereka memiliki kewajiban untuk terus bekerja pada Rumah Sakit Islam Ibnu Sina bukan karena ada rasa kewajiban moral 
bagi diri mereka untuk tidak meninggalkan perusahaan. Kecenderungan Hubungan karyawan yang baik dengan perusahaan tidak membuat karyawan merasa terikat dan mempercayai nilai harus loyal pada perusahaan tempat mereka bekerja saat ini. Perbedaan ini dapat disebabkan oleh faktor lokasi penelitian. Bloemer melakukan penelitian di Bank yang ada di Belgia sedangkan penelitian ini dilakukan di Rumah Sakit yang ada di kota Pekanbaru. Perbedaan lokasi penelitian dapat menghasilkan respon yang berbeda, karena sangat mungkin segmen yang berbeda memiliki respon pada model penelitian yang sama. Kita ketahui bahwa penghasilan rata-rata karyawan di Indonesia rendah, sehingga karyawan tidak merasa harus melakukan balas jasa atau merasa berkewajiban moral untuk setia pada perusahaan karena mereka merasa pendapatan mereka pas-pasan. Sesuai data dari Badan Pusat Statistik (BPS) menyatakan 60\% atau 50,15 juta orang pekerja yang dibayar (karyawan) di Indonesia masih berpenghasilan rendah. Rata-rata penghasilan mereka US\$ 2.284 per tahun (detikfinance.com).

Dalam penelitian ini menemukan bahwa salah satu dimensi sikap loyalitas, komitmen afektif merupakan dimensi variabel yang paling penting dalam membentuk salah satu perilaku loyalitas yaitu keinginan menetap (intention to stay) pada karyawan Rumah Sakit Islam Ibnu Sina Pekanbaru. Dengan demikian, karyawan yang memiliki ikatan emosional yang kuat terhadap perusahaan ternyata memiliki pengaruh terhadap perilaku keinginan mereka untuk terus bekerja pada Rumah Sakit Islam Ibnu Sina karena mereka memang ingin melakukan hal tersebut. Hal ini Sesuai dengan penelitian yang dilakukan Bloemer (2006) bahwa komitmen afektif pada karyawan mempengaruhi perilaku intention to stay pada karyawan. Demikian juga penelitian yang dilakukan Grant dkk, (2001), meyer dkk (1993) menemukan hubungan yang negatif antara komitmen organisasi dan turnover intentions. Turnover intentions adalah kecenderungan atau tingkat dimana seorang karyawan memiliki kemungkinan untuk meninggalkan organisasi, dimana turnover intention merupakan kebalikan dari perilaku intention to stay.

Hasil selanjutnya menunjukkan bahwa pengaruh komitmen kalkulatif dan komitmen normatif karyawan terhadap keinginan menetap (Intention to Stay) karyawan pada Rumah Sakit Islam Ibnu Sina ternyata tidak signifikan pengaruhnya. Ini membuktikan jika karyawan memiliki komitmen kalkulatif dan normatif yang kuat tidak mempengaruhi secara signifikan keinginan mereka untuk tetap bekerja di perusahaan. Hal ini sejalan dengan penelitian Bloemer (2006) yang menemukan bahwa komitmen kalkulatif pengaruhnya tidak signifikan terhadap Intention to stay pada karyawan. Berbeda dengan penelitian yang dilakukan oleh Hersusdadikawati (2005) yang menyatakan bahwa komitmen kalkulatif memiliki pengaruh yang negatif signifikan terhadap keinginan berpindah kerja pada karyawan. Pada penelitian Bloemer (2006) ditemukan bahwa komitmen normatif memiliki pengaruh yang signifikan terhadap keinginan menetap karyawan.

Pada karyawan Rumah Sakit Islam Ibnu Sina diperkirakan keinginan karyawan untuk terus bekerja pada perusahaan (Intention to stay) dipengaruhi kuat oleh varibel lain yang tidak dimasukkan dalam penelitian ini. Keinginan karyawan untuk tetap bekerja di organisasi dipengaruhi oleh variabel seperti kepuasan karyawan, citra perusahaan, kondisi lingkungan kerja, atau gaya perilaku pemimpin. Sesuai dengan penelitian Kurniasari (2004) bahwa komitmen organisasi dan Job insecurity mempengaruhi turn over intention karyawan. Job Insecurity adalah kondisi dimana karyawan merasakan adanya kondisi yang serba tidak pasti yang melingkupi pekerjaannya di masa yang akan datang, reward yang didapat dan masa kerja. Job insecurity yang dirasakan terus menerus oleh karyawan dan dapat mempengaruhi kualitas kerja.

Selanjutnya komitmen afektif dan komitmen normatif memiliki pengaruh yang 
positif terhadap Positif Word of Mouth (WOM), sedangkan komitmen kalkulatif memiliki pengaruh yang negatif. Akan tetapi pengaruh komitmen afektif, komitmen kalkulatif dan komitmen normatif karyawan terhadap Positif WOM pada Rumah Sakit Islam Ibnusina ternyata tidak signifikan pengaruhnya. Berbeda dengan penelitian yang dilakukan oleh Bloemer (2006) yang menemukan bahwa komitmen afektif memiliki pengaruh yang signifikan terhadap positif WOM, sedangkan dimensi variabel yang lainnya tidak signifikan pengaruhnya terhadap positif WOM. Perbedaan ini mungkin disebabkan karena perbedaan karakteristik individu dan perbedaan kondisi internal perusahaan yang mempengaruhi sikap dan perilaku karyawan. Sesuai dengan pernyataan Thoha (2008) bahwa organisasi sebenarnya bisa mempengaruhi perilaku karyawan dengan cara mengubah satu atau lebih faktor-faktor penentu dari perilaku individu. pada Rumah Sakit Islam Ibnu Sina, sikap loyalitas karyawan ternyata tidak mempengaruhi Perilaku Positif WOM mereka. Adanya perilaku positif WOM pada karyawan muncul karena dipengaruhi adanya rasa bangga terhadap perusahaan. Menurut Yasir dkk (2009) faktor paling penting sebagai pendorong munculnya rasa bangga karyawan terhadap perusahaannya, yaitu perusahaan memberikan bayaran yang dirasakan karyawan lebih baik dibanding pesaingnya atau rata-rata pada industri yang sama, citra perusahaan, dan persepsi konsumen terhadap produk perusahaan.

Pada komitmen kalkulatif dan komitmen normatif memiliki pengaruh yang positif terhadap ketidakpekaan terhadap benefit (Benefit Insensitivity) karyawan pada Rumah Sakit Islam Ibnu Sina. Sedangkan komitmen afektif memiliki pengaruh yang negatif. Akan tetapi pengaruh komitmen afektif, komitmen kalkulatif dan komitmen normatif karyawan terhadap keinginan menetap karyawan pada Rumah Sakit Islam Ibnu Sina ternyata tidak signifikan pengaruhnya. Berbeda dengan penelitian yang dilakukan oleh Bloemer (2006) yang menemukan bahwa komitmen afektif dan komitmen normatif memiliki pengaruh positif dan signifikan terhadap benefit insensitivity, sedangkan komitmen kalkulatif memiliki pengaruh yang negatif dan signifikan. Seperti yang telah dijelaskan sebelumnya bahwa karyawan merasakan penghasilan mereka dari perusahaan paspasan atau relatif kecil. Jadi hal ini yng mendorong mereka memiliki perilaku ketidakpekaan terhadap benefit karena penghasilan yang mereka dapatkan dari perusahaan kecil.

Selanjutnya komitmen afektif dan komitmen kalkulatif memiliki pengaruh yang positif terhadap perilaku komplain karyawan pada Rumah Sakit Islam Ibnu Sina, sedangkan komitmen normatif memiliki pengaruh yang negatif terhadap perilaku komplain. Akan tetapi pengaruh komitmen afektif, komitmen kalkulatif dan komitmen normatif karyawan terhadap perilaku komplain karyawan pada Rumah Sakit Islam Ibnu Sina ternyata tidak signifikan pengaruhnya. Berbeda dengan penelitian yang dilakukan oleh Bloemer (2006) yang menemukan bahwa komitmen afektif memiliki pengaruh positif dan signifikan terhadap perilaku komplain karyawan, sedangkan komitmen kalkulatif dan komitmen normatif memiliki pengaruh yang negatif dan signifikan terhadap perilaku komplain karyawan. Tidak signifikannya setiap pengaruh komitmen terhadap perilaku komplain pada karyawan mungkin disebabkan karena karyawan tidak terbiasa melakukan komplain pada perusahaan tempat mereka bekerja. Budaya masyarakat setempat yang tertutup yang masih melekat pada perilaku karyawan di Indonesia menyebabkan karyawan jarang melakukan perilaku komplain. Menurut Ravianto (2008), salah satu sifat-sifat tenaga kerja Indonesia yang telah membudaya sejak lama yaitu Sungkan, rendah diri, jiwa budak, nrimo dan pasrah (menerima apa adanya). Karakter demikian cenderung menyebabkan mereka kurang kreatif dan kurang memiliki keberanian untuk memberikan komplain atas kebijakan perusahaan. 


\section{SIMPULAN}

Kecenderungan hubungan karyawan (Employee Relationship Proneness) yang tinggi hanya memiliki pengaruh yang berarti terhadap komitmen afektif karyawan pada Rumah Sakit Islam Ibnu Sina Pekanbaru, akan tetapi tidak memiliki pengaruh yang berarti terhadap komitmen kalkulatif dan komitmen normatif. Hal ini disebabkan karena nilai-nilai ibadah dalam sebuah pekerjaaan tertanam kuat pada diri karyawan. Sehingga karyawan yang memiliki kecenderungan hubungan baik dengan perusahaan berpengaruh terhadap ikatan emosional mereka yang kuat melalui nilainilai agama yang ditanamkan perusahaan terhadap diri karyawan.

Dalam penelitian ini menemukan bahwa pada dimensi sikap loyalitas, hanya komitmen afektif yang mempengaruhi salah satu dimensi perilaku loyalitas yaitu keinginan menetap (intention to stay) pada karyawan Rumah Sakit Islam Ibnu Sina Pekanbaru. Sedangkan pada dimensi-dimensi variabel sikap loyalitas lainnya tidak memiliki pengaruh yang berarti terhadap perilaku loyalitas karyawan. Hal ini ini disebabkan karena karyawan yang memiliki ikatan emosional yang kuat terhadap perusahaan ternyata memiliki pengaruh terhadap perilaku keinginan mereka untuk terus bekerja pada Rumah Sakit Islam Ibnu Sina seperti yang mereka inginkan.

\section{DAFTAR RUJUKAN}

Aditama, Tjandra Yoga., 2003., Manajemen Administrasi Rumah Sakit. Jakarta : UI Press

Aktami, Bayu. 2008. (Tesis). Kontribusi Kepuasan Kerja Dan Iklim Organisasi Terhadap Komitmen Karyawan. Program Program Magister Psikologi Universitas Gunadarma

Allen, N.J. and Meyer, J.P. 1990, "The measurement and Antecedents of Affective, Continuance, and Normative Commitment to The Organization",
Journal of Occupational Psychology Vol.63, pp.1-18

Amin. 2007. Dasar-dasar Penulisan Ilmiah. Surakarta: Lembaga Pengembangan Pendidikan UNS

Andrian, Harry. 2010. Kekuatan Sebuah Internal Marketing. Bussiness\&accounting for better business practices. Melalui http://akuntansibisnis.wordpress.com.

Balthasar Elu. 2004. Strategi Manajemen Pemasaran Jasa Kesehatan. Jakarta:

Manajemen Usahawan Indonesia No.06/TH.XXXIII Juni 2004: 35-40.

Bendapudi, N. and Berry, LL. 1997. "Costumers Motivations For Maintaining Relationships With Service Providers", Journal of retailing, Vol. 73 No. 1 pp.15-37

Bilson, Simamora.2004. Panduan Riset Perilaku Konsumen. Jakarta : PT Gramedia Pustaka Utama.

Boy S.Sabarguna. 2004. Pemasaran Rumah Sakit. Yogyakarta: Konsorsium RSI 1-21.

Chaplin, C.B. 1995. Kamus Lengkap Psikologi. (Terjemahan: Kartini Kartono).ed 1. cetakan ke-2. Jakarta: Grafindo Persada

Cristy,R,Oliver,G.and Penn,J. 1996,"Relationship Marketing in consumer markets", Journal of Marketing Management, Vol 12, pp. 175-87.

De Wulf, K, Oderken-Schroder,G. and labocci, D. 2001. "How and Why retailers should invest in consumer relationships: a cross-countryindustry exploration", Journal of Marketing, Vol. 65 No.4, pp.33-50.

Dick, AS and Basu, K. 1994. Customer Loyalty : toward and integrated 
conceptual framework. Journal of academy of Marketing Science, Vol 22 No.2, pp. 99-113

Djati,Pantja. 2004. Pentingnya Karyawan dalam Pembentukan Kepercayaan Konsumen Terhadap Perusahaan Jasa: (Suatu kajian dan Proposisi). Jurnal Manajemen \& Kewirausahaan Vol. 6, No. 2, September 2004: 114 - 122

Eflina, Debora. dan Seniati, Liche. 2004, Pengaruh Kepribadian dan Komitmen Organisasi terhadap Organizational Citizenzhip Behavior. Makara Sosial Humaniora, Vol. 8, No. 3, Desember 2004: 105-111

Grant, K., D.W. Cravens, G.S. Low dan W.C. Moncrief, 2001, The Role of Satisfaction with Territory Design on The Motivation, Attitudes, and Work Outcomes os Sales People, Journal of The Academy of Marketing Science, Vol. 29, No.2, pp.165-178.

Gummesson, E. 2000, "Internal Marketing in the Light of Relationship Marketing and Network Organizations", in Lewis, Barbara and Varey, Richard (eds.), Internal Marketing. London: Routledge.

Hair Jr, Joseph .F, Rolph E Anderson, Ronald L. Tatham and William C. Black 1995 ,

Multivariate Data Analysis with Readings, Fourth Edition, Prentice Hall

International Editions.

Hair JR. F.Joseph ; Black C William ; Babbin J Barry. 2010. Multivariate Analysis ; Seventh Edition : Prentice Hall

Irving, G. P., Coleman, D. F. \& Cooper, C. L. 1997. "Further Assesments of a ThreeComponent Model of Occupational Commitment: Generalizability and Differences Across Occupations".
Journal of Applied Psychology. Vol. 82. No. 3. p. 444-452. Academic Press, Inc., California.

Kementrian kesehatan republic Indonesia. Daftar rumah sakit di Provinsi Riau. Melalui .http: depkes. Go.id

Kotler, Philip. 2007. Manajemen Pemasaran : Jilid I, Edisi Bahasa Indonesia. Jakarta : PT Indeks Kelompok Gramedia

Kotler, Philip. 2009. Manajemen Pemasaran : Jilid II, Edisi Bahasa Indonesia. Jakarta : PT. Indeks Kelompok Gramedia

Liljander, V. and Strandvik, T. 1993. Estimating Zones of Tolerance in Perceived Service Quality and Perceived Serviced value. Intenational Journal of Service Industry Management, Vol 4 No.2, pp. 6-28

Lupiyoadi, Rambat \& A. Hamdani. 2006. Manajemen Pemasaran Jasa. Edisi ke-2. Jakarta : Salemba 4

Martini, Y. \& Rostiana. 2003. "Komitmen Organisasi ditinjau dari Iklim Organisasi dan Motivasi Berprestasi”. Phronesis. Vol. 5. No. 9. p. 21-31.

Patria Jati, Sutopo. 2009. Nambah Ilmu Tentang manajemen Rumah Sakit. Melalui http://Scribd.com

Primalita, Ratni. 2008. Pengaruh Sistem Penyampaian Jasa terhadap Citra Rumah Sakit dan Dampaknya terhadap Kepercayaan Pelanggan pada Rumah Sakit Umum di Sumatera Barat. Disertasi Universitas Padjajaran. Melalui http://www.damandiri.or.id 
Program Pascasarjana Universitas Riau, 2009. Buku Pedoman Penulisan Tesis dan Disertasi, Unri Press, Pekanbaru

Rangkuti, Freddy.2007. Riset Pemasaran. Jakarta: PT Gramedia Pustaka Utama

Sandy, Adisutiyono. 2010. Internal Marketing. Melalui http://sandy adisutiyono.blogspot.com/

Sekaran, Uma.2006. Reseach Method For Bussiness, 4 th ED. Salemba 4

Soekanto. 1993. Kamus Sosiologi. Jakarta : PT. Raja Grafindo

Sugiyono. 2008. Metode Penelitian Bisnis. Bandung :Alfabeta

Supriyanto, S. 2010. Pemasaran Industri Jasa Kesehatan. Yogyakarta: penerbit Andi offset

Tjiptono, Fandi .2000. Manajemen Pemasaran Jasa. Yogyakarta: penerbit Andi offset

Witasari, Lia. 2008. (Tesis) Analisis Pengaruh Kepuasan Kerja Dan Komitmen Organisasional Terhadap Turnover Intentions (Studi Empiris Pada Novotel Semarang). Program Magister Manajemen, Program Pascasarjana Universitas Diponegoro, Semarang
Yamin, Sofyan : Heri Kurniawan. 2009. Stuructural Equation Modeling: Belajar lebih mudah teknik Analisis data kuesioner dengan Lisrel - PLS. Jakarta : Salemba Empat

Yasir, Sugianto : Machasin; Rambat Lupiyoadi. 2009. Intim Dengan Pelanggan, Sebagai Basis Strategi Bersaing. Jakarta : Lembaga Penerbit Fakultas Ekonomi Universitas Indonesia

Zeithaml, VA; Bitner, 2000. Conceptual Model Service Quality. Journal of Marketing Volume 49, Fall, pp. 1220.

Zeithaml, VA Berry, LL. And Parasuraman, A. 1996. The Behavioral Consequences of service quality, Journal of marketing, vol. 60, pp. 3146 